\title{
Serum calcium levels in rheumatoid arthritis
}

\author{
D. L. SCOTT, M. FARR, C. F. HAWKINS, R. WILKINSON, AND \\ A. M. BOLD
}

From the Rheumatism Research Wing and Departments of Medicine and Clinical Chemistry, Queen Elizabeth Hospital, Birmingham

SUMMARY Total and corrected (for albumin) serum calcium levels were investigated in a crosssectional study of 394 patients with rheumatoid arthritis, 4490 healthy subjects, and 2609 inpatients at a district general hospital. Patients with rheumatoid arthritis had lower mean calcium levels than the healthy subjects $(p<0.001)$, but had similar levels to inpatients at the district general hospital. Thirty-eight inpatients with rheumatoid arthritis at a hospital for rheumatic diseases had lower mean corrected and total calcium levels than all other groups $(p<0 \cdot 01)$. Corrected or total calcium levels higher than $2.60 \mathrm{mmol} / \mathrm{l}$ or corrected calcium levels lower than $2.20 \mathrm{mmlo} / \mathrm{l}$ were uncommon in the patients with rheumatoid arthritis. A longitudinal study of serum calcium levels in 17 patients with rheumatoid arthritis over 6-48 months showed considerable temporal variation in total and corrected calcium levels. Transient hypercalcaemia and hypocalcaemia occurred occasionally, but for most of the time calcium levels were normal. Changes in calcium levels were not related to changes in clinical, haematological, or immunological parameters of disease activity. Mean serum calcium levels are lower in disease than health; this occurs in RA as well as other diseases.

There is continuing interest in the metabolic changes occurring in rheumatoid arthritis (RA). Serum calcium levels are low in some patients with RA, ${ }^{1}$ and both Maddison and Bacon ${ }^{2}$ and O'Driscoll and O'Driscoll ${ }^{3}$ have described osteomalacia in association with RA. However, one recent study ${ }^{4}$ suggested that hypercalcaemia is a common occurrence in RA.

To resolve these conflicting reports we have further investigated serum calcium levels in RA.

\section{Materials and methods}

\section{CROSS-SECTIONAL STUDY}

Three groups of patients with classical or definite RA $^{5}$ were studied. These were: (a) 201 ambulant outpatients (67 males, 134 females; mean age $52 \cdot 3$ years, SD 13.3); (b) 155 inpatients at a district general hospital (61 males, 94 females; mean age 59.2, SD 12.2); (c) 38 inpatients at a hospital for rheumatic diseases (11 males, 27 females; mean age 57.0 years, $\mathrm{SD} 10 \cdot 8$ ).

There were 2 control groups. The first consisted of 4490 healthy subjects attending a screening clinic for the healthy. The second consisted of 2609 inpatients

Accepted for publication 15 December 1980

Correspondence to Dr D. L. Scott, Investigative Pathology, Rheumatism Research Wing, The Medical School, Birmingham. at a district general hospital. These were all the patients admitted in 1979 who had biochemical profiles performed with estimation of their serum calcium and albumin levels, with the following exceptions: (a) patients on specialised units (intensive care, renal dialysis, cardiovascular surgery, oncology); (b) patients with abnormalities in other biochemical parameters (sodium, potassium, urea, alkaline phosphatase, aspartate aminotransferase); (c) patients with very high or low calcium or albumin levels (outside 3 SD of the healthy subjects' mean values).

\section{LONGITUDINAL STUDY}

Seventeen patients with classical or definite $\mathrm{RA}^{5}$ were followed over 6-48 months. They were each seen a mean of 10 times (range 4-21). Their mean age was 59 years (range 35-80); 5 were males and 12 females. The activity of their RA was assessed clinically (duration of morning stiffness, Ritchie index ${ }^{6}$ ); haematologically (estimations of haemoglobin and ESR), and immunochemically (C-reactive protein and haptoglobin levels ${ }^{7}$ ).

\section{CALCIUM, ALBUMIN, AND \\ ALKALINE PHOSPHATASE}

These were all determined by standard methods on an SMA 12-60 Technicon AutoAnalyser using 
Table 1 Serum calcium and albumin levels in patients with $R A$

\begin{tabular}{lclll}
\hline & Number & $\begin{array}{l}\text { Total calcium (mmolll) } \\
\text { mean } \pm S D\end{array}$ & $\begin{array}{l}\text { Albumin }(\mathrm{g} / \mathrm{l}) \\
\text { mean } \pm S D\end{array}$ & $\begin{array}{l}\text { Corrected calcium }(\text { mmolll) } \\
\text { mean }\end{array}$ \\
\hline $\begin{array}{l}\text { Outpatients with RA } \\
\text { Inpatients with RA at district general hospital }\end{array}$ & 201 & $2 \cdot 36 \pm 0 \cdot 11$ & $39 \cdot 3 \pm 4 \cdot 7$ & $2 \cdot 37 \pm 0 \cdot 11$ \\
$\begin{array}{l}\text { Inpatients with RA at hospital for } \\
\text { rheumatic diseases }\end{array}$ & 155 & $2 \cdot 28 \pm 0 \cdot 15$ & $34 \cdot 2 \pm 5 \cdot 2$ & $2 \cdot 38 \pm 0 \cdot 12$ \\
All patients with RA & 38 & $2 \cdot 20 \pm 0.09$ & $34 \cdot 0 \pm 3 \cdot 32$ & $2 \cdot 30 \pm 0.07$ \\
\hline
\end{tabular}

Table 2 Serum calcium and albumin levels in healthy subjects and hospital patients

\begin{tabular}{|c|c|c|c|c|c|c|c|c|c|}
\hline \multirow[b]{2}{*}{ Age } & \multirow[b]{2}{*}{ Sex } & \multicolumn{4}{|c|}{ Healthy subjects } & \multicolumn{4}{|c|}{ Hospital patients } \\
\hline & & Number & $\begin{array}{l}\text { Total } \\
\text { calcium } \\
(\text { mmolll }) \\
\text { mean } \pm S D\end{array}$ & $\begin{array}{l}\text { Albumin } \\
(g / l) \\
\text { mean } \pm S D\end{array}$ & $\begin{array}{l}\text { Corrected } \\
\text { calcium } \\
(\text { mmol/l) } \\
\text { mean } \pm S D\end{array}$ & Number & $\begin{array}{l}\text { Total } \\
\text { calcium } \\
(\text { mmol } / l) \\
\text { mean } \pm S D\end{array}$ & $\begin{array}{l}\text { Albumin } \\
(g / l) \\
\text { mean } \pm S D\end{array}$ & $\begin{array}{l}\text { Corrected } \\
\text { calcium } \\
(\text { mmol/ll }) \\
\text { mean } \pm S D\end{array}$ \\
\hline $40-49$ & $\mathbf{M}$ & 1006 & $2.47 \pm 0.08$ & $43 \cdot 48 \pm 2 \cdot 11$ & $2.41 \pm 0.08$ & 257 & $2 \cdot 37 \pm 0 \cdot 10$ & $41 \cdot 79 \pm 3 \cdot 46$ & $2 \cdot 34 \pm 0 \cdot 10$ \\
\hline $50-59$ & $\begin{array}{l}\mathbf{F} \\
\mathbf{M}\end{array}$ & 1000 & $2.44 \pm 0.09$ & $42 \cdot 38 \pm 2 \cdot 32$ & $2.40 \pm 0.09$ & 33 & $2 \cdot 36 \pm 0 \cdot 10$ & $41 \cdot 46$ & $2 \cdot 34 \pm 0 \cdot 10$ \\
\hline $50-39$ & $\begin{array}{l}\text { M } \\
\mathbf{F}\end{array}$ & 1232 & $2.46 \pm 0.09$ & $42 \cdot 98 \pm 2 \cdot 17$ & $2.41 \pm 0.09$ & 406 & $2 \cdot 36 \pm 0.09$ & $40.96 \pm 3.46$ & $2.34 \pm 0.08$ \\
\hline & $\mathbf{M}$ & $\begin{array}{r}1022 \\
124\end{array}$ & $2 \cdot 47 \pm 0 \cdot 10$ & $42 \cdot 43 \pm 2.08$ & $2 \cdot 43 \pm 0 \cdot 10$ & 420 & $2 \cdot 38 \pm 0 \cdot 12$ & $40 \cdot 70 \pm 3 \cdot 60$ & $2 \cdot 37 \pm 0 \cdot 12$ \\
\hline $00 \mathrm{~T}$ & $\mathbf{F}$ & 124 & $2 \cdot 46 \pm 0.09$ & $42 \cdot 45 \pm 2 \cdot 08$ & $2.41 \pm 0.09$ & 636 & $2 \cdot 35 \pm 0 \cdot 10$ & $39 \cdot 80 \pm 3 \cdot 64$ & $2 \cdot 35 \pm 0 \cdot 10$ \\
\hline & & $\begin{array}{r}106 \\
4490\end{array}$ & $2.47 \pm 0.09$ & $42 \cdot 26 \pm 2 \cdot 23$ & $2.43 \pm 0.09$ & 558 & $2 \cdot 35 \pm 0 \cdot 11$ & $39 \cdot 12 \pm 3 \cdot 60$ & $2 \cdot 34 \pm 0 \cdot 12$ \\
\hline up means & & 4490 & $2 \cdot 46 \pm 0.09$ & $42 \cdot 78 \pm 2 \cdot 22$ & $2.42 \pm 0.09$ & 2609 & $2 \cdot 36 \pm 0 \cdot 11$ & $40 \cdot 39 \pm 3 \cdot 54$ & $2 \cdot 35 \pm 0 \cdot 11$ \\
\hline
\end{tabular}

Technicon AutoAnalyser Methodology. Calcium levels were corrected for serum albumin with a correction factor of $0.10 \mathrm{mmol}$ calcium per $6.0 \mathrm{~g}$ of albumin. ${ }^{8}$

\section{Results}

CROSS-SECTIONAL STUDY

Mean total and corrected serum calcium levels were low in patients with RA in comparison to healthy controls $(P<0 \cdot 001)$ (Tables 1 and 2). Hospital inpatients had corrected calcium levels similar to those of the patients with RA, and their calcium levels were low in comparison with those of the healthy subjects $(P<0.001)$. Patients with $R A$ at the hospital for rheumatic diseases had lower total and corrected calcium values than all other groups $(P<0.01)$. Differences in calcium values between groups were not due to differences in age or sex. They were also not a factor of the correction (for albumin) used; using other corrections ${ }^{9}$ gave similar results.

Extremes in calcium levels (corrected calcium $<2 \cdot 20 \mathrm{mmol} / \mathrm{l}$; total or corrected calcium $>2 \cdot 60$ $\mathrm{mmol} / \mathrm{l})$ were uncommon in patients with RA (Table 3).

Although serum calcium levels were lowest in the patients with RA at the hospital for rheumatic diseases, serum alkaline phosphatase levels were not higher in this group. Serum alkaline phosphatase levels in the 3 groups of patients with RA were: outpatients 11.1 King-Armstrong (KA) units/dl (SD 3.8); inpatients at a district general hospital
Table 3 Incidence of hypercalcaemia and hypocalcaemia in patients with $R A$

\begin{tabular}{|c|c|c|c|c|}
\hline & \multicolumn{2}{|c|}{$\begin{array}{l}\% \text { with } \\
\text { hypercalcaemia } \\
(\text { Ca }>2 \cdot 60 \mathrm{mmol} / \mathrm{l})\end{array}$} & \multicolumn{2}{|c|}{$\begin{array}{l}\% \text { with } \\
\text { hypocalcaemia } \\
(\text { Ca }<2 \cdot 20 \text { mmol/l) }\end{array}$} \\
\hline & Total & Corrected & Total & Corrected \\
\hline \multirow{3}{*}{$\begin{array}{l}\text { Outpatients with RA } \\
\text { Inpatients with RA at } \\
\text { district general hospital } \\
\text { Inpatients with RA at } \\
\text { hospital for rheumatic } \\
\text { diseases }\end{array}$} & $1.0 \%$ & $0.5 \%$ & $6.0 \%$ & $2.5 \%$ \\
\hline & $1.3 \%$ & $2.0 \%$ & $22.6 \%$ & $1.3 \%$ \\
\hline & 0 & 0 & $39.5 \%$ & $2.6 \%$ \\
\hline
\end{tabular}

12.3 KA units/dl (SD 6.4); inpatients at a hospital for rheumatic diseases 10.6 KA units/dl (SD 3.1). For comparative purposes the range of alkaline phosphatase found in healthy subjects in our laboratory was 4-13 KA units/dl in males and 3-10 KA units/dl in females.

The effect of calcium and vitamin D supplements (1 tablet $B P C$ daily: $75 \mathrm{mg}$ calcium $(1.875 \mathrm{mmol})$ and $12.5 \mu \mathrm{g}$ (500 IU) vitamin D) were studied in inpatients with RA at the hospital for rheumatic disease. Table 4 shows that there were no significant differences $(P>0 \cdot 10)$ between patients receiving supplements and those who were not.

The effect of steroids on serum calcium levels was studied in detail in the 201 outpatients with RA; 47 of this group were receiving corticosteroids, usually as oral prednisolone. The results are summarised in Table 5. Total calcium levels were similar, but patients receiving steriods had slightly higher corrected calcium levels $(\mathrm{P}<0.05)$. 
Table 4 The effect of calcium and vitamin D supplements on serum calcium and albumin levels in inpatients with $R A$ at the hospital for rheumatic diseases

\begin{tabular}{|c|c|c|c|c|}
\hline & Number & $\begin{array}{l}\text { Total calcium } \\
(\text { mmol/l) } \\
\text { mean } \pm S D\end{array}$ & $\begin{array}{l}\text { Albumin } \\
(\mathrm{g} / \mathrm{l}) \\
\text { mean } \perp S D\end{array}$ & $\begin{array}{l}\text { Corrected calcium } \\
(\text { mmol/l) } \\
\text { mean } \leq S D\end{array}$ \\
\hline $\begin{array}{l}\text { Receiving calcium and vitamin D supplements } \\
\text { Not receiving supplements }\end{array}$ & $\begin{array}{l}16 \\
22\end{array}$ & $\begin{array}{l}2 \cdot 21 \pm 0.05 \\
2 \cdot 20 \pm 0.12\end{array}$ & $\begin{array}{l}34 \cdot 8 \pm 2 \cdot 1 \\
33 \cdot 4 \pm 3 \cdot 9\end{array}$ & $\begin{array}{l}2 \cdot 29 \pm 0.03 \\
2 \cdot 30 \pm 0.09\end{array}$ \\
\hline
\end{tabular}

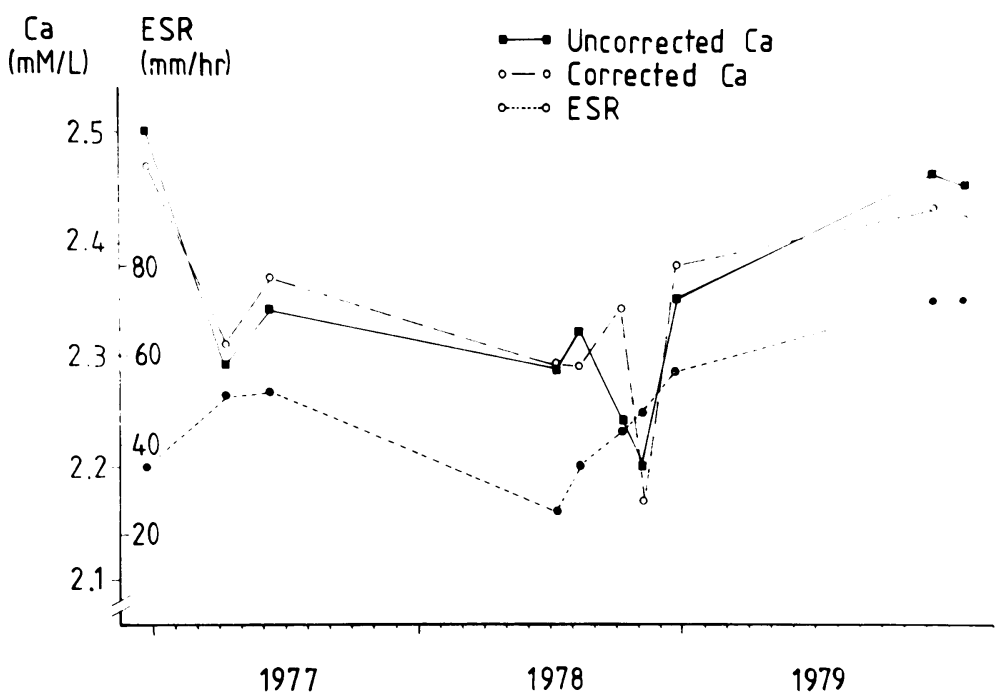

Fig. 1 Variations in total and corrected serum calcium and erythrocyte sedimentation rate (ESR). This patient showed an episode of hypocalcaemia.

Table 5 The effect of steroids on serum calcium cind albumin outpatients with $R A$

\begin{tabular}{lclll}
\hline & Number & $\begin{array}{l}\text { Total calcium } \\
(\mathrm{mmol} / \mathrm{l}) \\
\text { mean } \pm S D\end{array}$ & $\begin{array}{l}\text { Albumin } \\
(\mathrm{g} / \mathrm{l}) \\
\text { mean } \pm S D\end{array}$ & $\begin{array}{l}\text { Corrected } \\
\text { calcium } \\
\left(\text { mmol }^{\prime} l\right) \\
\text { mean })\end{array}$ \\
\hline $\begin{array}{c}\text { Receiving } \\
\text { steroids } \\
\begin{array}{c}\text { Not receiving } \\
\text { steroids }\end{array}\end{array}$ & 47 & $2.36 \pm 0.09$ & $38.0 \pm 4.9$ & $2 \cdot 39 \pm 0.08$ \\
\hline
\end{tabular}

\section{LONGIT UDINAL ST UDY}

The patients studied longitudinally often showed considerable variation in both total and corrected calcium values; these variations showed no consistent relationship to clinical, haematological, or immunological assessments of disease activity. However, in some patients total and corrected serum calcium levels were slightly higher when the ESR was elevated $(>50 \mathrm{~mm} / \mathrm{h})$ than when it was low $(<20 \mathrm{~mm} / \mathrm{h})$, although statistical analysis did not show a significant correlation. Some had transient episodes of hypocalcaemia or hypercalcaemia. Examples are shown in Figs 1 and 2.

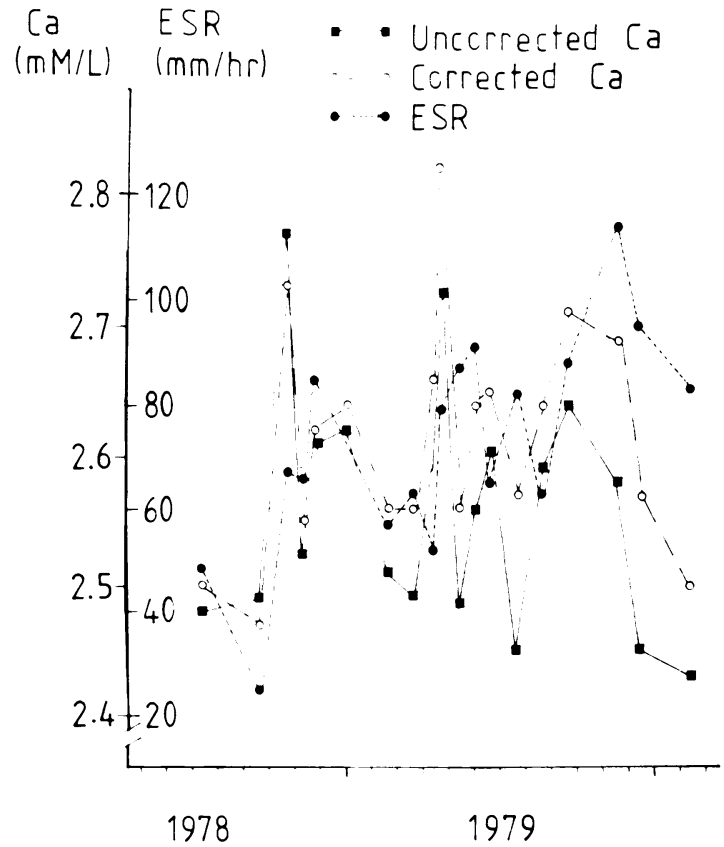

Fig. 2 Variations in total and corrected serum calcium and erythrocyte sedimentation rate (ESR). This patient had several episodes of hypercalcaemia. 


\section{Discussion}

Our results show that, although serum calcium levels in patients with RA are lower than in healthy subjects, this fall is not confined to patients with RA but is common in hospital patients. Some of these differences may be the result of factors such as posture, but in part they may result from disturbed calcium metabolism in disease states. Sodium metabolism is similarly affected in disease. ${ }^{10}$

Vitamin D is one important component of calcium metabolism. The patients at the hospital for rheumatic diseases given calcium and vitamin D supplements still had low serum calcium levels, suggesting such levels were not due to osteomalcia. Similarly, alkaline phosphatase levels were not elevated in this group of patients with RA in comparison with either the outpatients with RA or the inpatients with RA at the district general hospital. A recent survey by Bird et al. ${ }^{11}$ has not shown any evidence of abnormal 25-hydroxycholecalciferol levels in RA. However, there are other important metabolites of vitamin $D,{ }^{12}$ and it is possible that the intermediate metabolism of vitamin D may be abnormal in RA. Although reports on cases with RA and osteomalacia ${ }^{2,3}$ have drawn attention to the coexistence of these 2 diseases, they have not determined the incidence of osteomalacia in RA. Our study has not been designed to determine the incidence of osteomalacia, and further work is needed to resolve this important question.

The value of correcting serum calcium levels for albumin will always be controversial. ${ }^{9}$ However, the use of correction factors is justifiable in groups of patients and when extremes are not included. ${ }^{13-15}$ The significance of our findings is unchanged by using any of the described correction factors, and we have analysed statistically only data derived from groups of patients.

Although hypercalcaemia in hospital patients is not rare and is often due to hyperparathyroidism, ${ }^{16}$ we have found no evidence that hypercalcaemia is associated with RA. This is a different conclusion from that reached by Kennedy et al. ${ }^{3}$ in a detailed study of small numbers of patients with RA, and their generalisation that hypercalcaemia is common in RA is questionable. A further recent report of ionised calcium levels in $\mathrm{RA}^{17}$ has not shown a significant incidence of hypercalcaemia. One important observation in our study which is not directly related to calcium metabolism concerns the validity of control groups. Our results show that healthy subjects are different from hospital patients, and we suggest that controls should be matched not only for age and sex but also for the presence or absence of disease. By using only one of the 2 control groups incorrect conclusions may have been drawn.

We conclude that serum calcium levels are lower in disease than in health, and this occurs in RA as well as other diseases. There is no indication at present to treat many of these marginally low calcium levels.

We thank Mrs Margaret Peters and Mrs Ann Gregory of the Wolfson Research Laboratories, Queen Elizabeth Hospital, Birmingham, for assistance in the study of control data.

\section{References}

1 Dyer N H, Kendall M J, Hawkins C F. Malabsorption in rheumatoid disease. Ann Rheum Dis 1971 ; 30: 626-30.

2 Maddison P J, Bacon P A. Vitamin D deficiency, spontaneous fractures, and osteopenia in rheumatoid arthritis. $B r$ Med J 1974; iv: 433-5.

3 O'Driscoll S, O'Driscoll M. Osteomalacia in rheumatoid arthritis. Ann Rheum Dis 1980; 39: 1-6.

4 Kennedy A C, Allam B F, Rooney P J, et al. Hypercalcaemia in rheumatoid arthritis: an investigation of its causes and implications. Ann Rheum Dis 1979; 38: 401-12.

5 American Rheumatism Association. Diagnostic criteria for rheumatoid arthritis. 1958 revision. Ann Rheum Dis 1959; 18: 49-53.

6 Ritchie D M, Boyle J A, McInnes J M, et al. Clinical studies with an articular index for the assessment of joint tenderness in patients with rheumatoid arthritis. $Q J \mathrm{Med}$ 1968; 37: 393-406.

7 McConkey B, Davies P, Crockson R A, et al. Effects of gold, dapsone, and prednisolone on serum $\mathrm{C}$-reactive protein and haptoglobin and the erythrocyte sedimentation rate in rheumatoid arthritis. Ann Rheum Dis 1979; 38: $141-4$.

8 Bold A M, Wilding P. Clinical Chemistry Companion. Oxford: Blackwell Scientific, 1978.

9 Anonymous. Correcting the calcium. Br Med J 1977; i: 598.

10 Payne R B, Lovell M J. Redefinition of the normal range for serum sodium. Clin Chem 1968; 14: 172-8.

11 Bird H A, Peacock M, Storer J H, Wright V. Comparison of serum $25-\mathrm{OH}$ vitamin D concentrations in rheumatoid arthritis and osteoarthrosis. Br Med J 1980; i: 1416.

12 Norman A W, Schaefer K, Herrath D V, et al. Vitamin D, Basic Research and its Clinical Application. Berlin and New York: Waller de Gruyter, 1979.

13 Payne R B, Little A J, Williams R B, Milner J R. Interpretations of serum calcium in patients with abnormal serum proteins. $\mathrm{Br}$ Med J 1973 ; iv : 643-6.

14 Conceicao S C, Weightman D, Smith P A, Luno J, Ward M K, Kerr D N S. Serum ionised calcium concentration: measurement versus calculation. Br Med J 1978; i: 1103-5.

15 Walker B E, Payne R B. Serum ionised calcium concentration. Br MedJ 1978; i: 1352.

16 Mundy G R, Cove D H, Fisken R. Primary hyperparathroidism: changes in the pattern of clinical presentation. Lancet 1980; i: 1317-20.

17 Bramble M G, Blake D R, White T, Sly J, Kerr D N S. Ionised calcium in rheumatoid arthritis: effect of nonsteroidal anti-inflammatory drugs. $\operatorname{Br} M e d J 1980 ; 281$ : 840-1. 